\title{
Odontologia legal: a importância do DNA para as perícias e peritos
}

\section{Forensic dentistry: the importance of DNA to the examination by the experts}

\author{
Emanuela Maria Sartori Zenóbio Sena Franco Silveira1
}

Silveira EMSZSF. Odontologia legal: a importância do DNA para as perícias e peritos. Saúde, Ética \& Justiça. 2006;11 (1/ 2):12-8.

RESUMO: O presente estudo procurou realizar uma revisão de literatura para demonstrar o que é, e o que a Odontologia Legal é capaz de fazer para identificação de corpos humanos, auxiliar na solução de crimes através da utilização do DNA proveniente da cavidade oral. Demonstrou também a legislação que regulamenta o exercício da profissão e utilização de programas que envolvem seres humanos e seu DNA. Casos foram relatados para exemplificar como o DNA extraído de dentes e saliva é um importante dado forense.

DESCRITORES: DNA. Odontologia legal/legislação \& jurisprudência. Dente. Saliva. Identificação da prótese dentária. Biologia molecular.

\section{INTRODUÇÃO}

A biologia molecular, DNA, vem desempenhando um papel de grande importância nas identificações em casos mais complexos, onde os vestígios biológicos são praticamente virtuais, como uma gota de saliva, por exemplo, e a Odontologia Legal vem participando cada vez mais destes processos de identificação.

O Odontolegista é um profissional que possui um papel fundamental em vários casos de identificação humana e mesmo assim ele ainda não vem sendo requisitado com a freqüência que deveria, seu campo de atuação é vasto, abrangendo conhecimento extenso.

O Odontolegista deve estar familiarizado com os laboratórios que processem exames de DNA porque ele não é um mero captador e encaminhador de materiais, ele é um profissional completo ${ }^{19}$.

A Odontologia Legal é a especialidade que aplica os conhecimentos odontológicos, sem exceção, desde anatomia e matérias básicas, até as mais complexas especialidades como dentística, prótese, ortodontia, odontopediatria, periodontia, cirurgia buco-

\footnotetext{
1 Cirurgiã Dentista pela Universidade de Itauna, Especialista em Odontologia Legal e Deontologia pela Universidade Federal de Juiz de Fora.

Endereço para correspondência: Av. Cel Pedro Paulo Penido, 88. Ap. 101. Bairro Cidade Nova. Belo Horizonte, MG. CEP 31170-330. e-mail: emanuelazenobio @ terra.com.br
} 
maxilo-facial, endodontia e radiologia, aos interesses dbDieto.

O papel mais comum do Odontolegista, também conhecido como Dentista Forense é a identificação de falecidos através de registros dentais ante mortem quando possível. Com o avanço da tecnologia do DNA o odontolegista emprega evidencias dentais para inclusive ajudar a solucionar crimes violentos ${ }^{5}$.

\section{LEGISLAÇÃO}

É impossível falar sobre Odontologia Legal e DNA sem citar as leis que devem ser respeitadas para não ocorrer violação de princípios ou normas:

$>$ Lei no. 4.324 de 14 de abril de 1964 - Criações do Conselho Federal e Conselhos Regionais de Odontologia

$>$ Lei no. 5.081 de 24 de agosto de 1966 Regulamenta o exercício da Odontologia no Brasil;

$>$ Lei 803 de 8 de dezembro de 1994 - criação da Divisão de Pesquisa de DNA Forense - DPDNA, órgão diretivo, subordinado ao Departamento de Polícia Técnica da Polícia Civil do Distrito Federal;

$>$ Lei de Biosegurança no. 8974 de 1995 estabelece normas de segurança e fiscalização na utilização da engenharia genética;

> Declaração Universal do Genoma Humano e Direitos Humanos de 11 de novembro de 1997;

$>$ Lei 10.054, de 7 de dezembro de 2000-insere o exame de DNA para identificação criminal;

$>$ Resolução do Conselho Federal de Odontologia 22 de 27 de dezembro de 2001 Estabelece a competência de cada um dos integrantes da profissão odontológica;

$>$ Código de Ética Odontológico - Capítulo IV - das auditorias e perícias odontológicas.

A Lei 5.081 foi editada dois anos após a Lei 4.324 o que atestou definitivamente a maioridade da profissão odontológica. A partir dela compete aos conselhos, a fiscalização do exercício da odontologia no Brasil.

No Título I, Capítulo VIII, Seção IV, da Resolução Conselho Federal de Odontologia (CFO) 22. 27/12/2001, diz respeito a Odontologia Legal:

Art. 54 - Odontologia Legal é a especialidade que tem como objetivo a pesquisa de fenômenos psíquicos, físicos, químicos e biológicos que podem atingir ou ter atingido $o$ homem, vivo, morto ou ossada, e mesmo fragmentos ou vestígios, resultando lesões parciais ou totais, reversíveis ou irreversíveis. Parágrafo Único: A atuação da Odontologia Legal restringe-se a análise, perícia e avaliação de eventos relacionados com a área de competência do cirurgião dentista, podendo, se as circunstâncias o exigirem estender-se a outras áreas, se disso depender a busca da verdade, no estrito interesse da justiça e da administração.

Art. 55 - As áreas de competência para atuação do especialista em Odontologia legal incluem:

a) Identificação humana;

b) perícia em foro cível, criminal e trabalhista;

c) perícia em área administrativa;

d) perícia, avaliação e planejamento em informática;

e) tanatologia forense;

f) elaboração de autos, laudos e pareceres; relatórios e atestados;

g) traumatologia odonto-legal;

h) balística forense;

i) perícia logística no vivo, no morto, íntegro ou em suas partes fragmentadas;

j) perícia em vestígios correlatos, inclusive de manchas ou líquidos oriundos da cavidade bucal ou nela presentes;

k) exames por imagem para fins periciais;

l) Deontologia odontológica;

m) orientação odonto-legal para o exercício profissional;

n) exames por imagens para fins odontolegais.

A Declaração Universal do Genoma Humano e Direitos Humanos defende sobretudo a dignidade e direitos dos indivíduos, contra discriminações com base nas características genéticas; proteção desses indivíduos nas pesquisas realizadas tornando seus dados genéticos armazenados com confidencialidade assegurada.

\section{Perícias e Peritos}

Segundo $\mathrm{Cabral}^{4}$ perícia é uma diligência realizada ou executada por peritos, a fim de esclarecer ou evidenciar certos fatos. Significa, portanto, a investigação, o exame, a verificação da verdade, ou realidade de certos fatos por pessoas que tenham habilitação profissional; reconhecida experiência quando à matéria e idoneidade moral. O perito é uma pessoa que, pelas habilitações e qualidades 
especiais, instrui os autos no que tange à averiguação dos fatos dando subsídios para que o Juiz julgue com sabedoria. Ao perito não cabe julgar o fato, somente fornecer os elementos, não deve se importar com a posição social das partes envolvidas, devendo assim mostrar imparcialidade no laudo pericial. O perito deve sempre proceder com serenidade.

Perícias, de um modo geral, são operações designadas a ministrar esclarecimentos técnicos à justiça ${ }^{6}$.

Falsa perícia é crime previsto no Código Penal Brasileiro, artigo 342 com pena de reclusão de 1 a 3 anos e aplicação de multa.

As Perícias Odonto-legais podem ser ${ }^{14}$ :

\section{Perícias na Área Civil:}

$>$ Ressarcimento de danos: erro profissional, lesões na face, acidentes em que a vítima necessite de tratamento odontológico;

$>$ exclusão de paternidade: DNA, arcos dentários, doenças genéticas transmitidas ao campo bucodentário;

$>$ arbitramento judicial de honorários profissionais: cobrança quando não há acordo sobre os honorários profissionais

$>$ estimativa de idade: adoção de menores;

> avaliação de equipamentos odontológicos.

\section{Perícias na Área Criminal:}

> Identificação: no vivo (idade não comprovada de delinqüentes, marcas de mordida em alimentos ou na vítima), no cadáver (corpos carbonizados, dilacerados, estado avançado de putrefação, afogados, acidentes de massa), antropológicas (no crânio esqueletizado para verificar, espécie, sexo, idade, estatura, biótipo);

$>$ lesões corporais ou perícias de traumatologia;

$>$ determinação da idade;

$>$ perícia de manchas: diagnóstico diferencial de manchas de saliva;

$>$ exame de embriaguez: saliva.

\section{Perícias Trabalhistas:}

> Acidentes ocorridos na face e boca ou doenças profissionais com manifestação bucal.

\section{Perícias em Sede Administrativa: $>$ Perícia de convênio.}

As lesões a serem periciadas pelos CirurgiõesDentistas não se limitam ao aparelho estomatognático em si, mas se estendem por todo o corpo, nos casos de marcas de mordida em casos como atentado violento ao pudor, estupro ou simplesmente lesões corporais, onde a confrontação pode permitir identificar um suspeito ou, até mais importante, inocentar um já condenado. E também não se limitam ao corpo humano, como faz parecer o nome do exame: "exame de corpo de delito", que pode ser realizado em objetos inanimados, como frutas, queijos, doces e outras guloseimas encontradas em local de crime ${ }^{22}$.

\section{O DNA}

O DNA (ácido desoxirribonucléico) é uma molécula de cadeia longa cuja "coluna vertebral" possui alterações regulares entre grupo fosfato e açúcares; para cada açúcar é fixada uma base nitrogenada específica que pode ser de quatro tipos diferentes: adenina, guanina, citosina, timina ${ }^{21}$.
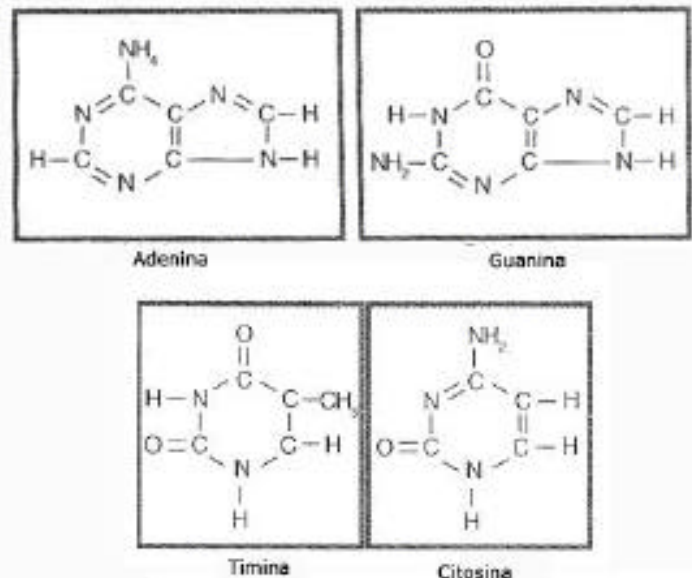

Figura 1. Bases nitrogenadas ${ }^{8}$

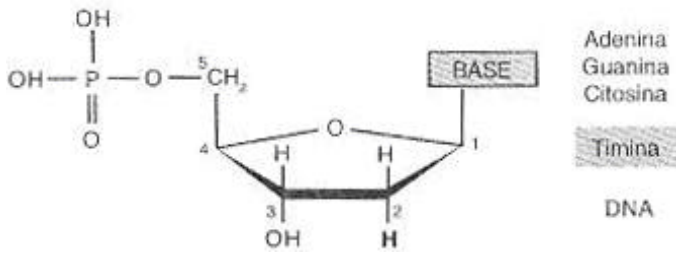

Figura 2. Fórmula estrutural da molécula de $D N A^{8}$

O DNA é um polímero orgânico encontrado em todas as células do organismo ${ }^{10}$.

De acordo com Pardini et al. ${ }^{12}$ é uma macromolécula responsável pela transmissão das características hereditárias, organizada ao longo de 23 pares de cromossomos no genoma humano e possui vários marcadores que servem como base

Saúde, Ética \& Justiça, São Paulo. 2006;11(1/2):12-8. 
para identificação humana.

Segundo Watson e Berry ${ }^{20}$ a hereditariedade é um dos aspectos mais relevantes do mundo natural e, talvez mais importante, é algo fácil e universalmente observável.

\section{O DNA nos tecidos bucais}

Os dentes, principalmente a polpa dentária, são importantes fontes de DNA ${ }^{13}$.

Segundo Silva ${ }^{14}$ os dentes resistem melhor do que qualquer tecido humano à degradação post mortem, variações de pressão e temperatura e isto possibilita a preservação da identidade genética individual.

Gaytmenn et al. ${ }^{7}$ afirma que os dentes são fonte útil de DNA principalmente em acidentes de massa, onde a identificação por outras vias se torna impossível. Para ele, mesmo se o dente estiver fragmentado é possível fazer a coleta e análise do DNA.

De acordo com Budowle et al. ${ }^{3}$, as mitocôndrias são organelas que contêm DNA específico separado do DNA nuclear. Ele relatou ainda que o DNA mt (mitocondrial) é herdado da mãe, pois o genoma mitocondrial masculino é destruído durante ou logo após a fecundação, sendo assim o DNAmt é idêntico entre irmãos e parentes maternos. É particularmente vantajoso que o DNA nuclear quando a quantidade de DNA extraída é pequena para análise. Ossos e dentes contem DNAmt. Segundo ele nenhum campo abraçou as ferramentas da biologia molecular mais que a ciência forense. Por mais de quinze anos os métodos de análise de DNA vêm sendo utilizados mundialmente para solucionar identidades em crimes violentos, atentados terroristas, desastres em massa e pessoas desaparecidas.

No estudo feito por Lufting ${ }^{10}$ sobre DNA mitocondrial presente nos dentes, ele relatou que os processos odontoblásticos regridem com o avanço da idade e por isso não se sabe ao certo se eles são completamente desintegrados ou se há restos de DNAmt. Se houver restos de DNAmt presente nesta região, ele estaria bem protegido e seria ótima fonte de estudo na identificação de corpos em decomposição.

As marcas de mordida humana são uma evidencia frequentemente encontrada em crimes de natureza sexual e devido às dificuldades de se comparar o local do dano físico em superfícies elásticas (pele) com a arcada dentária do suspeito, o DNA salivar é fundamental para descoberta do agressor $^{16}$.

De acordo com Vanrell19, o DNA salivar se mantém estável e pode ser recuperado sobre a vítima viva ou no cadáver dependendo do tempo em que ocorreu a lesão.

\section{A importância do dentista nos IMLs}

Segundo Malthus ${ }^{22}$ como pode existir um Instituto Médico-legal sem a presença de um Cirurgião-Dentista. Será que o Médico saberá periciar corretamente uma lesão na cavidade oral? Saberá interpretar um odontograma? Saberá extrair todas as informações necessárias para a identificação de um putrefeito, esqueletizado ou carbonizado? Um Instituto sem um Odontolegista é um IML incompleto. O trabalho de um Odontolegista em um IML compreende, dentre outros:

> Perícia no vivo, como lesões corporais, determinação de idade; perícia no morto, necroscopia e identificações; e perícias em instrumentos e próteses.

\section{A importância histórica e jurídica do DNA proveniente de tecidos bucais}

Para Lijnen e Wilems ${ }^{9}$ a recente análise de DNA apresentada à odontologia forense para identificação de indivíduos utilizando material genético extraído de dentes e saliva, apesar de muito boa, ainda é uma questão de debate e crítica no meio jurídico.

As investigações científicas que fundamentam as decisões jurídicas ganharam uma base extremamente sólida com os avanços alcançados na tecnologia em DNA. Os testes realizados com os ácidos nucléicos apresentam uma base de identificação positiva, permitindo aos peritos das áreas biológica ou jurídica tomarem decisões de caráter definitivo. Até outrora, os métodos tradicionais de tipagem sorológica apresentavam diversos fatores limitantes, como por exemplo, não tinham um grau de heterogeneidade, de polimorfismo, e especialmente de acuracidade, suficientes para uma inclusão de identidade; pelo contrário, apoiavam-se somente em alguns casos isolados, onde o diagnóstico era exclusivamente o de exclusão ${ }^{11}$.

As investigações criminais ganharam força com o auxílio da tecnologia biomolecular através da análise de DNA salivar deixados em objetos e restos de alimentos nas cenas de crime, inclusive em marcas nos corpos das vítimas (relato de casos no. 1).

Algumas páginas de história podem ser reescritas apos análises de DNA dentário realizado em múmias, corpos esqueletizados, restos mortais (relato de casos $n^{\circ}$. 3 ), e mesmo com o passar dos anos, dúvidas podem ser retiradas e esclarecidas como no caso da criança não identificada no naufrágio do Titanic ocorrido em abril de 1912 (relato 
de casos $n^{\circ} .5$ ).

A identificação através do DNA dentário é muito importante e uns dos melhores exemplos que podem ser citados foi sua utilização na identificação das vítimas do Tsunami, tragédia ocorrida em dezembro de 2004 (relato de casos no. 4).

\section{RELATO DE CASOS}

1. Saliva encontrada em uma mordida em um

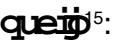

No local do crime a polícia encontrou um pedaço de queijo que continha uma marca de mordida. Esse pedaço de queijo foi recolhido como prova e congelado para preservar as características da marca da mordida e saliva que estava presente em pequena quantidade. Após a análise e determinação do DNA encontrado na saliva, a polícia comparou com DNA dos suspeitos e descobriu o verdadeiro criminoso.

\section{DNA dentário de um corpo incinerado ${ }^{17}$}

O corpo da vítima encontrava-se totalmente carbonizado, com suspeita de homicídio, sem possibilidade de identificação visual, porém a maioria dos dentes sobreviveu ao intenso calor. Foi feita a coleta do DNA da polpa dentária da vítima e isto foi fundamental para a investigação do crime.

3. Dentes de Viking mudam a história (Estado de Minas, 2005):

Graças a resultados de testes de DNA em dentes encontrados em uma tumba real na Dinamarca, com cerca de mil anos, uma página da história dos Vikings precisará ser reescrita. Por mais de 500 anos, historiadores acreditaram que o corpo do último rei viking Sven Estridsen, foi depositado ao lado do de sua mãe Estrid em 1074. Segundo informa a revista inglesa New Scientist, um teste na polpa dos molares extraídos dos esqueletos na tumba da Catedral de Roskilde, na ilha de Sjaelland, mostrou que os corpos ali não são mãe e filho. Jorgen Dissing, do Instituto de Medicina Forense, testou as amostras de DNA mitocondrial, pois é um componente transmitido pela linhagem materna. As amostras do esqueleto masculino não combinam com o esqueleto feminino, provando que Estrid enterrada ali, não era a mãe de Sven.

Os dentes e ossos sugerem ainda que a mulher enterrada ali, quando morreu tinha aproximadamente 35 anos e históricamente a mãe do rei Sven teria falecido com 75 anos. Dissing acha que a mulher enterrada com Sven deve ter sido uma das noras do rei que também tinha o nome de Estrid.

4. DNA dentário na identificação de vítimas do Tsunami²:

O devastador Tsunami que ocorreu na Ásia Oriental em dezembro de 2004 tornou muito difícil à identificação das vitimas. Vários dentistas foram chamados, dentre eles Gareth Pearson e John Clement, para executar a difícil tarefa de identificar os corpos por análise de DNA dentário e estudo das arcadas. Aproximadamente $75 \%$ dos corpos foram identificados por análise de dentária. A grande vantagem do DNA dentário é sua auto preservação, o que permitiu que Odontolegistas continuassem trabalhando nas identificações por meses após a tragédia, pois outras amostras de DNA não se preservam na ausência de refrigeração adequada. Até fevereiro de 2005 haviam sido identificados 400 corpos, em abril o número cresceu para mais de 1200 , até julho foram mais de 1700 . Até setembro de 2005 foram identificados 2200 corpos. O sucesso da identificação se deveu à competência e concentração da vasta equipe de odontolegistas que foram designados, independente de nacionalidades.

5. Identificação de vítima do naufrágio do Titanic ${ }^{18}$ :

Dr. Ryan Parr e Alan Ruffman iniciaram o projeto Titanic Ancient DNA em 1998. Eles requisitaram permissão para exumar 3 corpos enterrados no cemitério de Fairview Lawn. O motivo era de se identificar uma criança não identificada. As exumações ocorreram em maio de 2001. Em dois corpos não se pode fazer nada devido ao alto grau de decomposição dos restos mortais, porém no terceiro corpo foi possível identificar um pequeno fragmento de osso e três dentes. Havia suspeitas de que o corpo fosse de Gosta Leonard Palsson, mas em 2002 esta hipótese foi descartada após análise do DNA mitocondrial presente no fragmento ósseo e descendentes maternos vivos. Após esse fato, o foco central tornou-se o dente da criança. Dr. Ruffman se prontificou em encontrar parentes de seis crianças do sexo masculino que morreram no naufrágio do Titanic; os parentes encontrados doaram amostras de sangue para análise comparativa de DNA. A análise do DNA mitocondrial do dente 84 foi surpreendente, pois foram encontrados dois parentes da criança até então não identificada. Depois de muitas pesquisas descobriu-se que Sidney Leslie Goodwin de 19 meses e Eino Viljam Panula de 13 meses, tinham a mesma descendência materna de cerca de 2000 anos atrás e por isso o DNA mitocondrial das amostras das duas famílias foram idênticas. 
Entretanto observando as características do grau de desenvolvimento e maturação do dente a conclusão foi de que a criança não identificada era Eino Viljam Panula.

\section{CONCLUSÃO}

A biologia molecular vem se tornando cada vez mais importante e seus métodos na utilização da identificação de seres humanos estão em constante evolução, o Odontolegista é um profissional que acompanha e faz parte desta evolução.

\section{ANEXO}

1. O Estado do Rio de Janeiro ganhou no dia 01 de fevereiro de 2005 o primeiro laboratório de DNA para investigação policial, através de uma parceria do Governo Estadual e Federal. O laboratório de DNA Forense tem padrão de qualidade internacional, aparelhos de análise genética que funcionam ligados a computadores, gerando arquivos digitais.

2. Em Santa Catarina a instalação do laboratório de DNA forense era uma antiga reivindicação dos técnicos do IGP - Instituto Geral de Perícias - que se concretizou em abril de 2006 devido a parceria entre Secretaria da Segurança Pública e Defesa do Cidadão com o Ministério da Justiça.

3. De acordo com Roger Ancilotti, diretor do IML do Rio de Janeiro, a identificação de algumas vítimas do acidente aéreo ocorrido no dia 31 de março de 2006 será feita pela análise de DNA e documentação odontológica, devido ao estado dos corpos que impossibilitam um reconhecimento visual.

Silveira EMSZSF. Forensic dentistry: the importance of DNA to the examination by the experts. Saúde, Ética \& Justiça. 2006;11(1/2):12-8.

ABSTRACT: This work seeks demonstrate what is, and how forensic dentistry is able to assist in solving crimes by identifying the human bosy using only oral cavity DNA. Also examined, are the laws that regulate this profession and programs that use human DNA. Various cases are described to illustrate how DNA extracted from teeth and saliva provide important forensic data.

KEY WORDS: DNA. Forensic dentistry/legislation \& jurisprudence. Tooth. Saliva. Denture identification marking. Molecular biology.

\section{REFERENCIAS}

1. Arbenz GH. Medicina legal e antropologia forense. São Paulo: Atheneu; 1988.

2. Bajai $A$. Disaster victim identification: Tsunami. $\mathrm{Br}$ Dent J. 2005;198(8):504-5.

3. Budowle B, Allard MW, Wilson MR, Chakraborty R. Forensics and mitochondrial DNA: applications, debates and foundations. Annu Rev Genomics Hum Genet. 2003;4:119-41.

4. Cabral AF. Manual da prova pericial. Niterói: Ed. Impetus; 2003.

5. Dizzino A, Saneet D. Personal identification through dental evidence - tooth fragments to DNA. J Calif Dent Assoc. 1996;24:5 35-42.

6. Figini ARL, Silva JRL, Jobim LF, Silva M. Identificação humana. 2a. ed. Campinas: Ed. Millenium; 2003. p.241-322.

7. Gaytmenn R, Sweet D. Quantification of forensic DNA from various regions of human teeth. J Forensic Sci. 2003;48:3:622-5.
8. Junqueira LC, Carneiro J. Biologia celular e molecular. 5a. ed. Rio de Janeiro: Guanabara Koogan; 1991.

9. Lijnen I, Willens G. DNA research in forensic dentistry. Methods Find Exp Clin Pharmacol. 2001;23:9:511-7.

10. Lufting MA, Richey S. DNA and forensic science. N Engl Law Rev. 2001;35(3):609-13.

11. Miyagima F. Aspectos fundamentais da validade jurídica das provas em DNA [dissertação]. Campinas: UNICAMP; 2001.

12. Pardini VC, Ferreira ACS, Gomes KB, Rodrigues SLB. Uso do DNA proveniente da polpa dentária para identificação humana. Rev CROMG. 2001;7:33-5.

13. Potsch L, Meyer U, Rothschild S, Schineider PM, Ritter C. Application of DNA techniques for identification using dental pulp as source of DNA. Int J Legal Med. 1992;139-43.

14. Silva M. Compêndio de odontologia legal. São Paulo: Ed. Medici; 1997. 
Silveira EMSZSF. Odontologia legal: a importância do DNA para as perícias e peritos.

15. Sweet $D$, Hildebrand $D$. Saliva from cheese bite yields DNA profile a burglar. Int $J$ Legal Med. 1999;113(3):201-3.

16. Sweet D, Lorente M, Lorente JA, Valenzuela A, Villanueva $\mathrm{E}$. An inaproved method to recover saliva from humam skin: the double swab technique. J Forensic Sci. 1997;42(2): 320-2.

17. Sweet $D$, Sweet $C H$. DNA analysis of dental pulp to link incinerated remains of homicide victims to crime scene. J Forensic Sci. 1995;40(2):310-4.

18. Titley KC, Pynn BR, Chernecky R, Mayhall JT, Kulkarni
GV, Ruffman A. The Titanic disater: dentistry's role in the identification of an unknown child. J C Dent Assoc. 2004;70(1):24-8.

19. Vanrell JP. Odontologia legal e antropologia forense. Rio de Janeiro: Guanabara Koogan; 2002.

20. Watson DJ, Berry A. DNA o segredo da vida. São Paulo: Cia. das Letras; 2005.

21. Watson DJ, Crick FHC. Molecular structure of nucleic acids. Nature. 1953;171.

22. Disponível em: http://www.malthus.com.br 